\title{
Statyba
}

\section{DEVELOPMENT OF RATIONAL MODEL FOR LITHUANIAN CONSTRUCTION INDUSTRY}

\section{E. K. Zavadskas , A. V. Rutkauskas \& A. Kaklauskas}

To cite this article: E. K. Zavadskas , A. V. Rutkauskas \& A. Kaklauskas (1999) DEVELOPMENT OF RATIONAL MODEL FOR LITHUANIAN CONSTRUCTION INDUSTRY, Statyba, 5:2, 123-134, DOI: $10.1080 / 13921525.1999 .10531446$

To link to this article: https://doi.org/10.1080/13921525.1999.10531446

曲 Published online: 26 Jul 2012.

Submit your article to this journal

LII Article views: 130

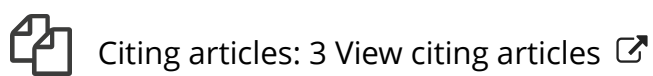




\title{
LIETUVOS RACIONALIOS STATYBOS ŠAKOS MODELIO KŪRIMAS
}

\author{
E. K. Zavadskas, A. V. Rutkauskas, A. Kaklauskas
}

\section{Statybos šaka šalies ekonominẻje sistemoje}

Nagrinejjant Lietuvos ekonomikos dinamiką ir struktūros pokyčius, matyti didelè sąryšiu ivaairovè. Tarp pramonès gamybos apimčiu ir BVP apimčiu yra ganètinai glaudus koreliacinis sąryšis netgi skirtingais ekonominès raidos ciklais ir tarpsniais, o statybos šakos sąryšis su BVP augimu yra nulemtas dar ir gausybẻs specifinių veiksnių.

Žinoma, statybos šaka labai priklauso nuo visos valstybẻs ekonomikos lygio. Pastatyti statiniai skiriami pramonès ir ivairioms aptarnavimo paslaugu imonems. Vykdomos statybos apimtys priklauso nuo statinių paklausos, o ji savo ruožtu kyla iš kitu produktu ir atliekamu paslaugu paklausos. Plétojantis šalies pramonei ir aptarnavimo paslaugoms, kyla j̨vairių rūšiu statiniu poreikis. Tad nemaža investuojamy i i ivairias veiklos sferas pinigy transformuojama i pastatus. $1992 \mathrm{~m}$. statybos produkcija sudarè $9,32 \%, 1993 \mathrm{~m}$. 7,76\%, 1994 m. - 8,74\%, 1995 m. - 6,67\%, 1996 m. 7,1\% BVP.

Kaip matome, Lietuvos statybos imoniu ir bendrovių atliktų darbų lygis nuolat svyruoja. Šie svyravimai priklauso nuo šalies ekonomikos pokyčių, vyriausybès vykdomos ekonominès ir socialinès politikos, gretimų valstybių ekonominès situacijos bei kitu veiksnių. Esant tokiai padečiai kyla klausimas, kaip objektyviai prognozuoti statybos produkcijos mastą ir jos dali BVP. Matyt, tam reikia pasitelkti visas galimybes. Viena iš galimybiu yra Lietuvos statybos šakos modeliavimas siekiant ištirti efektyvią statybos veiklos aplinka. Toliau bus nagrinejamos kai kurios Lietuvos statybos šakos egzistavimo proceso teorinio modelio sudarymo problemos.

\section{Lietuvos statybos šakos efektyvumo teorinis modelis}

Statybos šakos efektyvumo lygis priklauso nuo tam tikro dvieju lygmenu - mikro- ir makrolygmeny kintamuju skaičiaus. Nors makrolygmens veiksniai veikia visos šalies ar pramonès efektyvumo lygi, čia analizuojamas tik ju poveikis statybos šakos efektyvumui. Statybos šakos veiklos efektyvumas priklauso nuo ją kompleksiškai veikiančiu makrolygmens kintamuju veiksniu, tokiu kaip ekonominis, politinis ir kultūrinis šalies lygis, statybos šakos veiklą reglamentuojantys dokumentai, rinka, mokesčiu sistema, kredity gavimo galimybés ir sąlygos, infliacija, vietiniai ištekliai ir t. t. Priklausomai nuo bendrojo šiu makrolygmens veiksniu poveikio kinta statybos šakos efektyvumo lygis.

Statybos efektyvumo lygis taip pat priklauso nuo mikrolygmens kintamuju veiksnių (veiklos srities pasirinkimas, žemes sklypu ir pastaty kainos, statybos vietovès infrastruktūros, statybos informacinès sistemos, statybos šakos organizacijų susivienijimı veikla, integruotas pastato egzistavimo proceso projektavimas, statybos medžiagu ir gaminių tiekimo proceso efektyvumo didinimas naudojantis internetu ir pan.), kurie savo ruožtu priklauso nuo makrolygmens veiksnių. Pavyzdžiui, mokesčių sistema, nustatyta makrolygmeniu, vadovaujantis vyriausybès fiskaline politika, daro tiesiogini poveiki darbo užmokesčio dydžiui ir medžiagų kainoms mikrolygmeniu (projekto lygmeniu). Valstybès požiūris i konkrečią veiklą (ivairūs istatymai ir nutarimai, mokesčiu lengvatos, dotacijos, subsidijos ir pan.) daro didelę itaką organizaciju efektyvumui. Ivairiu suinteresuoty grupių (pavyzdžiui, užsakovo ir rangovo) santykius tiesiogiai reguliuoja istatymai. Kiekviena statybos organizacija turi tam tikrą statusą, kurị nulemia įstatymai. Šis statusas nustato organizacijos veiklos ribas ir mokamus mokesčius.

Norint užtikrinti vykdomo projekto efektyvumą, reikia atsižvelgti $\mathfrak{i}$ mikro- ir makrolygmens veiksniu nustatytas sąlygas. Keičiantis šiems veiksniams, keičiasi ir statybos šakos efektyvumo lygis. Tai bus trumpai pailiustruota toliau pateiktais dviem pavyzdžiais.

Lietuvos Vyriausybè, siekdama padèti gyventojams spręsti aktualias būsto problemas, gali panaikinti naujos gyvenamosios statybos pridètinès vertès mokestị. Šis išorinès makroaplinkos pokytis sumažins nauju gyvenamuju pastaty kainas bei padidins ju paklausą. 
Dèl to, padidejjus būsto statybos apimtims, padidès projektavimo darbu, statybos medžiagu ir gaminiџ poreikis ir pan. Taigi panaikinus pridetinès vertès mokestị ne tik padidètų ivvairiu statybos šakos organizaciju atliekamu darbu apimtys, bet ir sumažetų nedarbas.

Pastaruoju metu išsivysčiusios pasaulio šalys pradejo aktyviai diegti sistemas, kuriomis vykdoma statybos gaminiu paieška, prekyba ir tiekimas naudojant internetą. Pavyzdžiui, netolimoje praeityje Pietu Afrikos Respublikoje statybos gaminiu prekyba ir tiekimas buvo vykdomas menkai naudojantis informacinès technologijos galimybèmis. Todèl buvo bereikalingai gaištamas laikas, nukentédavo teikiamos informacijos tikslumas ir operatyvumas, pirkejai, nežinodami galimų variantų, kartais už prekes mokèdavo pernelyg didelę kainą. Siekiant išspręsti šias problemas bei padidinti informacijos mainy efektyvumą, internete buvo sukurta elektronine statybos gaminiy tiekimo sistema "eZebuild" (G. Coetzee, 1998). "eZebuild" dèka gamintojai, tiekejjai ir rangovai gavo veiksminga ir lengvą naudoti statybos gaminiu tiekimo valdymo iranki. Pavyzdžiui, rangovai gali tiesiogiai susisiekti su statybinių medžiagu gamintojais ar tiekẻjais, užsakyti norimas medžiagas ir už jas užmokèti internetu. Dabar galima lengviau surasti norimus statybos gaminius pigesnèmis kainomis, tiekimo procesas tapo vienodesnis ir efektyvesnis. Pagal šią sistemą statybos gaminiai atvežami i statybvietę laikantis grafiko, todèl jie statybvietėje laikomi trumpiau, sumažejo ju nuostoliai.

Kaip matome, statybos šakos veiklos galimybés bei efektyvumo lygis labai priklauso nuo racionaliai parinkty (idiegtu) mikro- ir makroaplinkos kintamuju veiksnių. Kitaip tariant, esant konkretiems mikro- ir makrolygmens kintamiesiems veiksniams iš karto objektyviai apribojama efektyvi statybos šakos veikla. Objektyviai apribota statybos šaka siekia efektyviai atlikti savo funkcijas. Suprantama, kai organizacijos priklauso nuo konkrečios mikro- ir makrolygmens aplinkos, geriausia savo veiklą plètoti tose statybos šakos srityse (projektavimas, statybos gaminiu, irankiu ir mechanizmu gamyba, gyvenamujų namų statyba, pastatu šiluminè renovacija, tiekimas ir t. t.), šalyse ir geografinèse vietovése (sostinè, ivvairūs šalies miestai ir rajonai, kaimo vietovès ir t. t.) ir su tomis suinteresuotomis grupèmis, kur visų šių grupių tikslai būtų maksimaliai igyvendinti (1 pav.). Remdamosi šiuo teiginiu, pirmaujančios organizacijos stengiasi susikurti racionalias vidinès ir išorinès aplinkos veiklos sąlygas, kad kuo geriau tenkindamos klienty poreikius pelnytų geresnę reputaciją ir gautų daugiau pelno.

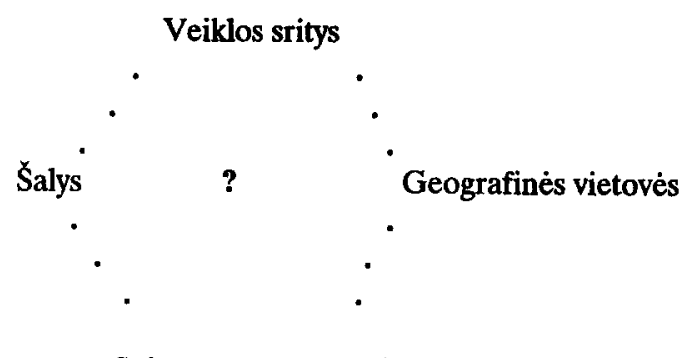

Suinteresuotos grupès

1 pav. Efektyvios statybos veiklos erdvès paieškos schema

Fig 1. Diagram of search for effective activities in construction industry

Vadovaujantis pateiktomis mintimis ir faktais, galima aiškiau suformuluoti šio straipsnio tikslą pateikti efektyvios Lietuvos statybos šakos teorinio modelio projekta, remiantis racionaliu mikro- ir makrolygmens kintamuju veiksniu paieška. Turèdamos tokị modeli statybos šakos organizacijos, atsižvelgdamos i mikro- ir makrolygmens aplinkos ribojimus bei galimybes, galès racionaliau naudoti savo išteklius. Šiuo atveju siūlomą modelị praktiniams tikslams galima būty taikyti tiek valstybès, tiek ir organizaciju lygmeniu.

Šiame tyrime modelis suprantamas kaip "žaidimų taisykliu sistema", kuriai esant Lietuvos statybos ડ̌aka geriausiai panaudoty savo potencialias galimybes.

Modeliuojant bei numatant statybos šakos ateities perspektyvas ir pagrindines pletros kryptis, galima iš anksto ruoštis efektyviems Lietuvos isstatymy bei įvairių organizaciju pokyčiams. Tai siūloma atlikti analizuojant išsivysčiusiu šaliy patirti bei žinias ir pritaikant Lietuvai. Analizuojant reikia sudaryti galimus valstybès (organizaciju) statybos Sakos strategijos variantus, juos ivertinti pagal daugiakriterinius analizés metodus ir išrinkti veiksmingiausius. Iš pradžiu ekspertiniais metodais nustatomi mikro- ir makrolygmens veiksniai ir juos apibūdinančios kriteriju sistemos ir posistemiai, išsamiai apibūdinantys statybos šakos veiklą. Remiantis šiais kriterijais koncepciškai ir kiekybiškai aprašoma statybos šakos padètis Lietuvoje ir išsivysčiusiose šalyse. Remiantis sukaupta medžiaga nustatomos išsivysčiusiu šaliu statybos šakos plètros kryptys ir ju bei Lietuvos šios srities skirtumai. Išanalizavus Lietuvos ir išsivysčiusiu šaliu statybos šakos skirtumus mikro- ir makrolygmeniu galima nustatyti Lietuvos statybos šakos plétros tendencijas bei prognozuoti ateiti. Analizuojant atsiranda reali galimybe sudaryti ịvairius galimus mikro- ir makrolygmens veiksniu derinius, juos išnagrinèti ir pateikti konkrečias rekomendacijas. 


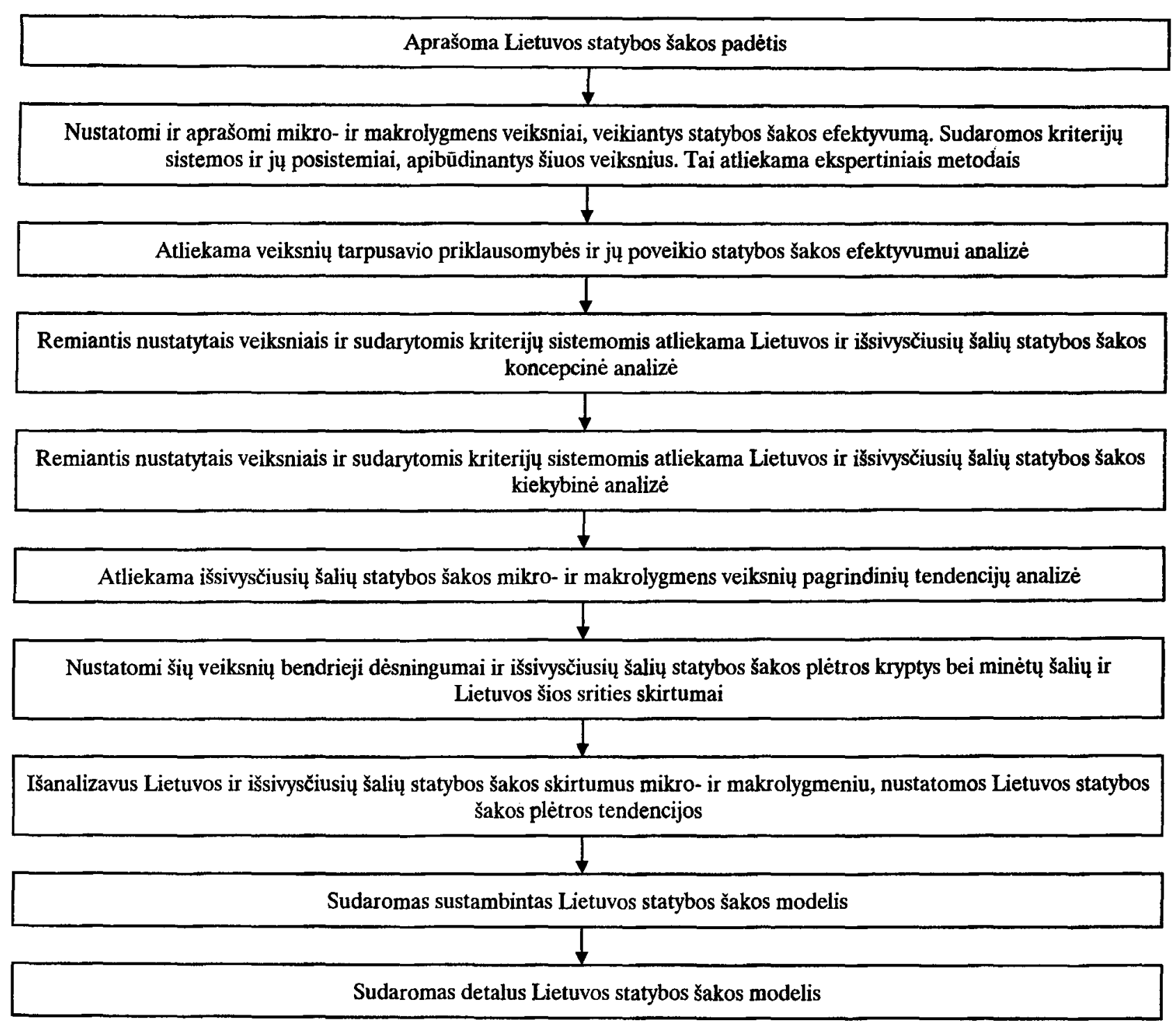

2 pav. Teorinio Lietuvos racionalios statybos šakos modelio kūrimas

Fig 2. The development of rational construction industry theoretical model for Lithuania

Nagrinèjant tik kelias išsivysčiusias šalis, galima prieiti prie gana subjektyviu išvadu. Tačiau nagrinèjant daugiau šaliu, analizès objektyrumo lygi galima padidinti.

Teorinis Lietuvos racionalios statybos šakos modelis buvo kuriamas remiantis 2 paveiksle pateiktais etapais. Kadangi šios analizès tikslas buvo sukurti teorini Lietuvos racionalios statybos šakos modeli, todèl visi etapai buvo nagrinejjami fragmentiškai, siekiant pateikti pasiūlyto metodo esmę kartu su ji iliustruojančiais pavyzdžiais.

Toliau trumpai aprašomi kai kurie racionalios statybos modelio sudarymo etapai.

\section{Pastato egzistavimo proceso aplinka ir jos poveikis statybos šakos efektyvumui}

\subsection{Makrolygmens veiksniai ir ju ịtaka statybos šakos efektyvumui}

Aukščiausias lygmuo, nuo kurio priklauso statybos šakos efektyvumas, yra makrolygmuo. Statybos sakos efektyvumą veikia tokie makrolygmens veiksniai:

- šalies ekonominis, politinis ir kultūrinis išsivystymo lygis,

- vyriausybès politika (regioninès paramos programos, konkurencijos reguliavimas, lengvatiniai kreditai, vyriausybiniai užsakymai, dotacijos, subsidijos, socialinè politika, mokesčiu sistema), 


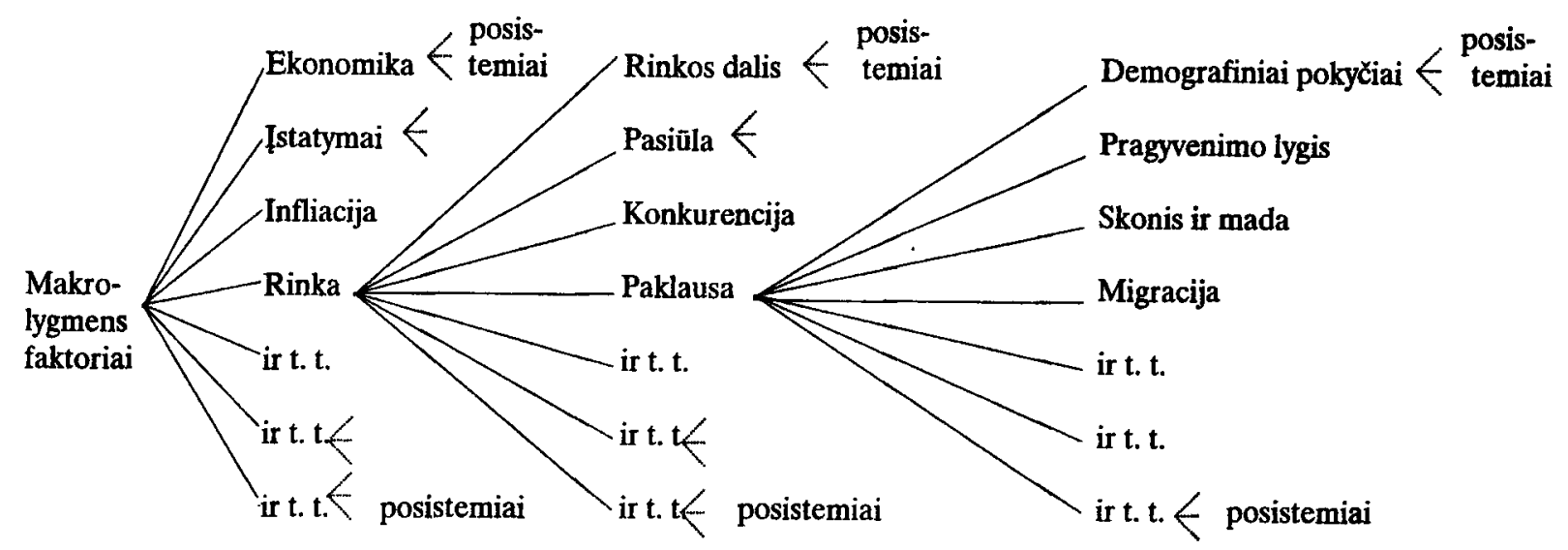

3 pav. Kriteriju, apibūdinančių makrolygmens veiksnius, sistemos ir posistemiai

Fig 3. Criteria systems and sub-systems characterising macroefficiency level factors

- teisiniai ir normatyviniai statybos šakos dokumentai,

- palūkanų normos,

- infliacija,

- rinka,

- draudimo sistemos, valiutų kursų svyravimai,

- muitai,

- nedarbo lygis,

- darbo jégos kvalifikacija,

- darbo užmokesčio lygis,

- darbo istatymai,

- aplinkosauga,

- papročiai ir tradicijos,

- vietiniu ištekliu buvimas ir t.t.

Norint išsamiai i̇vertinti minètu makrolygmens veiksniu ittaką statybos šakos efektyvumui, reikia juos išreikšti išsamiai apibūdinančiomis kriteriju sistemomis ir posistemiais (3 pav.). Tai iliustruojama rinka kaip pavyzdžiu.

Vienas iš svarbiausių klausimų, kuri sprendžia visos organizacijos ir nuo kurio labai priklauso jų efektyvumo lygis, yra rinkos tyrimai. Rinką ivertinti galima daugeliu kriteriju [1, 2]:

- paklausos lygis (apie ši rodikli galima gauti daugiau informacijos atsakius $i$ klausimus, kokie vartotojai, kodel, kiek, kada ir kaip perka tokią ir panašią produkciją, kurią siūlo nagrinèjama organizacija),

- pasiūlos lygis (apie ši rodikli galima gauti daugiau informacijos turint duomenu apie tiesioginius ir netiesioginius konkurentus bei ju strategijas),
- nagrinejjamos organizacijos ir jos konkurenty gaminamos produkcijos kainu lygis,

- rinkos dydis (kokia rinkos dalis tenka nagrinèjamai organizacijai),

- rinkos kitimo tendencija (kokios augimo galimybès, kaip keisis nagrinèjamos organizacijos rinkos dalis, jei rinka plèsis),

- nagrinejjamos organizacijos ir konkurenty stipriosios ir silpnosios pusès,

- produkcijos pirkèjo (atskiru asmenų) analizè (jo amžius, lytis, tautybè ar etninè grupé, mégstamas užsièmimas, išsilavinimas, gyvenimo būdas, socialinè priklausomybè, gyvenimo lygis, profesija, šeimyninè padètis ir pan.),

- produkcijos pirkéjo (ivairiu organizaciju) analizè (veiklos sfera, darbo vieta, struktūra, produkcijos pardavimo lygis, paskirstymo kanalai, darbuotoju skaičius),

- kas priima galutini sprendimą perkant produkciją,

- informacijos ir reklamos apie gaminamą produkciją platinimo galimybès.

Šiuos rinką apibūdinančius kriterijus galima analizuoti dar detaliau. Tai atliksime statybos produkcijos pasiūlos ir paklausos pavyzdžiu.

Statybos produkcijos paklausa priklauso nuo tokiy veiksnių:

- Kainos. Kuo žemesné kaina, tuo didesnè paklausa. Tai yra pirmoji paklausos ir pasiūlos dèsnio taisyklè.

- Palūkanu normos. Ekonomikoje skaičiuojama atsiŽvelgiant i tą faktą, kad pinigai statybos procesui finansuoti yra skolinami. Už Šiuos pinigus mokama palūkany norma. Didejant palūkanų normai mažè- 
ja užsakovy ir rangovy, norinčiu ją gauti. Todèl sulétèja statybos investicinis procesas.

- Realioji palūkany norma yra apytiksliai lygi palükany normos ir infliacijos lygio skirtumui. Savaime suprantama, kad pajamų norma turi būti didesnè už palūkanų normą.

- Kity produkty arba paslaugu kainos. Žmonès visada gali pinigus išleisti kitur: nusipirkti mašiną, buitinès technikos prekiu, pagerinti buities salygas ar gerai praleisti atostogas. Tai priklauso nuo konkretaus žmogaus poreikių, jo galimybių ir šiu produktų ar paslaugų kainu.

- Pajamos. Mažos pajamos neleidžia gyventojams pagerinti buities sąlygu tuo metu, kai daug statybininky yra bedarbiai. Augant pajamoms, dideja statybos produkcijos paklausa.

- Gyventojų skaičius. Keičiantis gyventojų skaičiui, keičiasi ne tik gyvenamujų namy paklausa, bet taip pat pramoniniu, socialinès paskirties ir kity pastaty paklausa.

- Pomègiai. Užsakovo pomégiai rodo šalies kultūros lygi, madas, ipročius, klimato sąlygas. Pomègius taip pat gali veikti reklama. Žmonès, norintys gyventi švarioje aplinkoje ar turèti atskirą namą, keliasi gyventi ị užmiestị, kur žemés kainos yra mažesnès. Pastatai, esantys ramiuose, respektabiliuose rajonuose, šalia mokyklų, parduotuviu, socialinès paskirties objekty ir visuomeninio transporto, turi didelę paklausą ir todèl brangiau kainuoja. Kaip matome, keičiantis pomègiams, keičiasi ir kainos.

- Vyriausybés politika. Viena vertus, valstybė yra didžiausias statybos šakos produkcijos naudotojas, kita vertus, ji reguliuoja fiskalinę, monetarinę, techninę ir kitas politikas, nuo kurių nemažai priklauso statybos šakos efektyvumas.

- Ateities perspektyvos. Pastaty paklausa didès, jeigu gyventojai manys, kad ateityje šiu pastatu kaina kils. Jeigu gyventojai galvos, kad ateityje pastaty kainos mažes, tai jie dabar namų tiesiog nepirks.

Pasikeitus minetiems paklausos faktoriams, keičiasi ir kainos.

Statybos šakos produkcijos pasiūla priklauso nuo daugelio veiksnių:

- Sąnaudos (statybos kaštai). Gamybos veiksniai tai žemè, darbas ir kapitalas. Žemę apibūdina jos kaina ar nuomos kaina, darba - atlyginimai, kapitala - palükany norma. Atliekamo darbo efektyvumas priklauso nuo darbuotojo kvalifikacijos ir motyvacijos. Statybos kaštai, o kartu ir paklausa, priklauso nuo šiu triju gamybos faktorių.

- Technologija. Tobulejjant technologijai, mažeja produkcijos kaina ir gereja jos kokybè.

- Kity panašiy prekiu kainos. Gaminami produktai gali pakeisti ar papildyti vienas kitą. Pavyzdžiui, panašių langu atpigimas sumažina pastatų atnaujinimo kainą.

- Kiti faktoriai. Pasiūla taip pat priklauso nuo kity faktorių: politinių sukretimu, karu, streiku, palūkany normos politikos ir pan.

Siekiant išsamiau apibūdinti minètus makrolygmens veiksnius, juos apibūdinančias kriterijı sistemas ir posistemius galima sudaryti analogiškai.

\subsection{Mikrolygmens veiksniai ir ju ittaka projekty efektyvumui}

Antrojo lygmens veiksnius, darančius itaką statybos šakos efektyvumui, galima vadinti mikrolygmenimi. Šie veiksniai priklauso nuo makrolygmens veiksnių (visą statybos šakos veiklą reglamentuoja įvairūs įstatymai, normatyviniai dokumentai ir pan.). Pavyzdžiui, galima teigti, kad jeigu mokesčiai yra pakankamai dideli, tai nacionalinès firmos dèl didelès mokesčiu naštos gali arba bankrutuoti, arba sumažinti savo efektyvumą (padidejjus mokesčiams, sumažès tarptautinių kompanijų, norinčiu įeiti ị vietinę rinką, konkurencija). Ir priešingai, sumažinus mokesčius, tarptautinès kompanijos, ịeidamos i vietinę rinką, gali arba išstumti nacionalines firmas iš ju rinkos dalies, arba nacionalinès firmos, susidūrusios su tokia konkurencija, bus priverstos padidinti savo efektyvumą. Šio proceso padariniai gali jaustis ịvairiose srityse (nedarbas, mokesčiu surinkimo lygio kitimas ir pan.).

Projektu efektyvumą veikia ivairūs mikrolygmens veiksniai:

- žemès sklypų ir pastaty kainos,

- statybos vietovès infrastruktüra,

- statybos informacinès sistemos,

- statybos organizaciju susivienijimai,

- veiklos srities pasirinkimas,

- integruotas pastato egzistavimo proceso projektavimas,

- statybos medžiagy ir gaminiy aprūpinimo proceso efektyvumo didinimas naudojant internetą,

- nenutrūkstamas mokymas,

- organizaciju finansavimas,

- sutarties tipas,

- tiksly nustatymo procesas, 
- projektavimo procesas,

- statybos procesas,

- eksploatavimo procesas,

- pastatu ūkio valdymas ir t. t.

Minèty mikrolygmens veiksniy įtaka statybos efektyvumui toliau trumpai iliustruojama komercinio kredito ir sutarties tipo pasirinkimo pavyzdžiu.

Firmos naudoja komercini kreditą, kuris padeda gauti reikiamus išteklius ar paslaugas iš karto, o imokos atidedamas vẻlesniam laikotarpiui (dažniausiai nuo dviejų iki triju mènesių). Santykinai didèjant palūkanų normai firmos stengiasi naudoti komercini kreditą. Tad nemokant palūkanų taupomi pinigai. Kai laiko tarpas tarp ištekliu pirkimo ir galutinés produkcijos pardavimo yra gana didelis (taip dažnai ir būna statyboje), tiekèjai gali suteikti ilgalaiki kreditą. Dažnai tiekejjai, suteikiantys komercinị kreditą, siūlo ankstesnị pinigu grąžinimą skatinančias nuolaidas. Ivertinus visas išlaidas ir nuolaidas, susijusias su komerciniu kreditu, galima padaryti išvadą, kad tai nèra pigus trumpalaikis finansavimas ir dažnai geriau naudoti kitus finansavimo šaltinius. Tačiau daugeliui mažų statybinių firmy geresniy trumpalaikių finansavimo šaltinių sunku surasti. Todėl komercinis kreditas joms lieka vienas iš svarbiausiy trumpalaikio finansavimo šaltinių. Komercinius kreditus dažnai naudoja statybos tiekèjai ir subrangovai, subrangovai ir rangovai, rangovai ir užsakovai.

Sutarties tipo pasirinkimą lemia daugelis veiksnių, turinčių ittakos projekto efektyvumui [3]:

- bendra savininko sutarčių politika,

- vietinio statybos personalo kvalifikacijos lygis,

- projektavimo ir statybos laikas,

- savininko pageidavimas kontroliuoti kai kurias projekto dalis,

- kainos svarba savininkui,

- rizikos lygis sudarant kontraktą,

- rangovy skaičius ir jų tinkamumas,

- vietovès klimatas,

- pasitikèjimo rangovu lygis,

- rangovo patirtis,

- prieškontraktinis periodas (ilgas, trumpas),

- konsultantai (rangovo ar užsakovo pasirinkimas),

- subrangovai (vietinis, paskirtas),

- pakeitimy ivertinimas (brangus, pigus, ta pati kaina).

Kiekvieno mikrolygmens veiksnio efektyvumą galima jvertinti remiantis adekvačiai ji aprašančia kriteriju sistema ir posistemiais. Tai galima pateikti analogiškai
3 pav., kuriame pateiktos makrolygmens veiksnius apibūdinančios kriterijų sistemos ir posistemiai.

\subsection{Veiksnių tarpusavio priklausomybe ir jų itaka statybos šakos efektyvumui}

Veiksniai veikia vieni kitus, taip pat jie daro bendrą poveiki statybos šakos efektyvumui. Toliau trumpai panagrinésime kai kurias šias tarpusavio priklausomybes.

Statybos šakos organizacijos yra labai jautrios monetarinès politikos pokyčiams ir ypač palūkanu normos didejjimui. Daugelyje šaliu nemaža atliekamų statybos darbu dalis finansuojama paimta paskola. Palūkanų normos didejimas ne tik mažina statybos produkcijos paklausą, bet taip pat sumažina statybos organizaciju pelningumo lygi. Pakilus palūkany normai, padidèja statybos kaina, sumažèja užsakymų. Kai kurios organizacijos, siekiančios išlaikyti užsakymus, mažindamos savo pelną, mažina statybos kainą. Organizacijos, kurios labai priklauso nuo paskolų, atsiduria ties bankroto riba. Todèl ten, kur monetarinè politika apriboja galimybes gauti paskolas ir padidina palükanų normas, statinių poreikis sumažèja. Kartu sumažèja statybos šakos veiklos apimtis.

Vyriausybè arba vietos valdžia skatina kai kurias investicijas, noredama, kad ivairios organizacijos investuotų lešas ị jų remiamą sritị. Investicijos gali būti skatinamos mažinant (pavyzdžiui, pelno, gauto iš investiciju, mokesčiu lengvatos) arba panaikinant kai kuriuos mokesčius. Taip skatindama investicijas, vyriausybė siekia sumažinti nedarbą, atnaujinti miestą, padèti plètotis rajonams ir pan.

Importuojamos ir eksportuojamos statybos šakos produkcijos ir paslaugy efektyvumas labai priklauso nuo valiuty kursy pokyčiu. Lietuvos statybos imonès importuoja daug metalo, kuro, kitų žaliavų. Nemaža Lietuvos statybininkų dirba užsienyje. Keičiantis valiutų kursams statybos organizacijos gali uždirbti daugiau arba mažiau, negu buvo planuota. Tokiais atvejais sunku atlikti tikslius ekonominius skaiciavimus, prognozuoti ateiti ir efektyviai plètoti statybos verslą. Todèl valiutu kursu svyravimai daro nemažą poveiki statybos šakos efektyvumui.

Ekonomistas K. Marsdenas šio amžiaus septintajame dešimtmetyje analizavo dvidešimties šalių ekonominio augimo ir mokesčių ryši. Dešimtyje tiriamų šalių buvo nustatyti dideli mokesčiai ir dešimtyje palyginti maži mokesčiai. Mažų mokesčlu šalyse sparčiai augo užimtumas, kapitaliniai ịdejjiniai ir darbo 
našumas ne tik privačiose, bet ir valstybinèse firmose. Žemu mokesčiu šalyse investicijos vidutiniškai padidejo $9 \%$, o dideliu mokesčiu šalyse jos sumažejo apie $0,8 \%$ per tą patị laikotarpi. Tyrimai rodo, kad pelno mokesčiu vienam padidejimo procentui investiciju augimo tempas sumažèja 2\% [4].

Dalaso universiteto ekonomistas Dž. Skali taip pat tyrinejo mokesči normą ir ekonominio augimo priklausomybę 103 šalyse. Jo tyrimai taip pat parodé, kad šalyse, kuriose mokesči norma siekè 19,3\%, ekonominis augimas tiriamuoju laikotarpiu sudare $24 \%$, o mokesčił normai esant $43,2 \%$, ekonominis augimas neviršijo $0,4 \%$ [4].

Lietuvoje kvalifikuota darbo jèga persilieja iš statybos $\dot{i}$ tas šakas, kur darbo užmokestis yra didesnis (pavyzdžiui, energetika, bankininkysté).

Daugelyje išsivysčiusiu pasaulio šaliu aplinkos saugojimas, oro, žemès ir vandenų užterštumo mažinimas yra viena iš pagrindiniu problemų, kurioms spręsti skiriamas labai didelis demesys. Prie šiu problemy sprendimo nemažai gali prisideti ir racionali statybos šakos veikla.

Daugelis mikro- ir makrolygmens veiksnių objektyviai apibrežia suinteresuotu grupių veiklos ribas:

- augant pajamoms, santykinès išlaidos kai kuriems produktams (pvz., maistui) mažeja, o kitiems (pvz., investicijoms) didèja;

- gamybos imonès, kuriose dirba daug ir žemos kvalifikacijos darbininkų, orientuojasi i gamybą su didesniu kapitalu ir aukštesnès kvalifikacijos specialistais;

- šalies pramonès specializacija priklauso nuo jos turimy gamtiniu (dirbama žemè, mineraliniai ištekliai, šalies dydis) ir intelektinių išteklių;

- besivystančioms šalims büdingos didesnès gavybos ir žemès ūkio sritys, o išsivysčiusioms šalims pramonès ir paslaugu sritys ir pan.

Pereinamojoje ekonomikoje gamybą veikia kai kurie faktoriai, paveldèti iš buvusios planinès ekonomikos, tokie kaip:

- aukštas formalaus išsilavinimo lygis,

- daug kvalifikuoty darbuotoju su santykinai mažais atlyginimais,

- santykinai senos ir ekonomiškai neefektyvios gamyklos,

- bũtinumas iš esmès perskirstyti išteklius tiek tam tikrose gamybos šakose, tiek ir tarp ju ir pan.

Statybos organizacijos negali koreguoti ar keisti minètu mikro- ir makrolygmens kintamuju, tačiau gali issisąmoninti ju poveiki ir juos ivertinti, igyvendinant ivairius projektus. Organizacijos, žinodamos mikro- ir makrolygmenu veiksnius, darančius poveiki igyvendinamiems projektams, gali sèkmingiau organizuoti savo dabartinę ir ateities veiklą.

\section{Statybos šakos aprašymas kiekybine forma}

Statybos šakos aprašymo kiekybine forma tikslumas priklauso nuo gaunamos informacijos visapusiškumo ir tikslumo bei sugebèjimo ją išreikšti matematiniu pavidalu. Bègant laikui informacijos tikslumo vaidmuo vis didèja. Aukščiausias informacijos tikslumo lygis yra pasiekiamas tada, kai ją galima išreikšti skaičiais. Todèl vienas iš pagrindinių teorinio Lietuvos racionalios statybos šakos modelio kūrimo uždaviniu yra adekvatus statybos šakos veiklos išreiškimas kiekybine forma.

Literatūroje [5] buvo atliktas Lietuvos ir Jungtinès Karalystès statybos šakos padeties koncepcinis ir juo pagrįstas kiekybinis aprašymas. 1 lentelèje pateiktas formalizuotas Lietuvos ir Jungtinès Karalystès statybos šakos padèties aprašymas kiekybine forma. Šioje lentelèje pateikti nagrinèjamų veiksnių pavadinimai, jų matavimo vienetai, reikšmingumai ir reikšmès.

Statybos šakos efektyvumą apibũdinantys kiekybiniai veiksniai išreikšti kiekybiniais matavimo vienetais, o kokybiniai veiksniai - balais. Kuo didesnès yra šiu kokybinių veiksnių reikšmès, tuo geresnès mikro- ir makrosąlygos yra sukurtos statybos šakai funkcionuoti. Kokybiniy veiksniy reikšmès buvo nustatytos tokiu būdu. Kadangi pagal šiuos veiksnius Jungtinè Karalysté (JK) yra pasiekusi didesniu laimèjimy negu Lietuva, todel JK suteikiamos maksimalios šį rodiklių reikšmès (10 balų). Remiantis kelių Lietuvos ekspertų nuomone, buvo nustatyta, kiek procenty situacija Lietuvoje yra blogesnè negu JK. Nustačius šiuos dydžius, Lietuvos kokybinił veiksnių reikšmès buvo apskaičiuotos pagal tokią formulę:

$$
x_{L i}=\frac{x_{J K_{i}}-a_{s i}}{10},
$$

$x_{L t_{i}}$ - Lietuvos kokybinių veiksnių reikšmès (balais); $x_{J K_{i}}-\mathrm{JK}$ kokybinį veiksnių reikšmés (balais); $a_{s i}$ dydis, parodantis, kiek procenty situacija Lietuvoje yra blogesnè negu Jungtinèje Karalystëje pagal šiuos rodiklius.

1 lenteleje veiksnių reikšmingumai parodo, kokią itaką jie turi bendram statybos šakos efektyvumo didinimui (efektyvesniu veiklos sąlygu sudarymui). 
1 lentelè. Fragmentinis Lietuvos ir Jungtinès Karalystès statybos šakos aprašymas kiekybine forma

Table 1. A fragment of mathematical description of the present state of construction in Lithuania and UK

\begin{tabular}{|c|c|c|c|c|}
\hline \multirow[t]{2}{*}{$\begin{array}{c}\text { Nagrinèjami } \\
\text { veiksniai }\end{array}$} & \multirow{2}{*}{$\begin{array}{c}\text { Veiksnių } \\
\text { matavimo } \\
\text { vienetai }\end{array}$} & \multirow{2}{*}{$\begin{array}{l}\text { Veiksnių } \\
\text { reikšmin- } \\
\text { gumai }\end{array}$} & \multicolumn{2}{|c|}{$\begin{array}{l}\text { Nagrinejamy̆ šalių } \\
\text { veiksnių skaitmeninès } \\
\text { reikšmès }\end{array}$} \\
\hline & & & Lietuva & JK \\
\hline$x_{1}$ & $m_{l}$ & $q_{1}$ & $x_{L 11}$ & $x_{J K 21}$ \\
\hline$x_{2}$ & $m_{2}$ & $q_{2}$ & $x_{L 12}$ & $x_{J K 22}$ \\
\hline$\ldots$ & $\ldots$ & $\ldots$ & $\ldots$ & $\ldots$ \\
\hline$x_{i}$ & $m_{i}$ & $q_{i}$ & $x_{L H}$ & $x_{I K 2 i}$ \\
\hline$\ldots$ & $\ldots$ & $\ldots$ & $\ldots$ & $\ldots$ \\
\hline$x_{n}$ & $m_{n}$ & $q_{n}$ & $x_{L I n}$ & $x_{J K 2 n}$ \\
\hline
\end{tabular}

Remiantis 1 lentelèje pateiktu Lietuvos ir JK statybos šakos kiekybiniu aprašymu, galime apytiksliai nuspręsti, kokioje pereinamojo laikotarpio stadijoje yra Lietuvos statybos šaka. Iš [5] literatūroje pateikto Lietuvos ir JK statybos šakos koncepcinio aprašymo išsamaus vaizdo taip pat nesusidaroma. Todèl vien kiekybinio arba koncepcinio aprašymo neužtenka, reikia taikyti abu būdus. Kiekybini aprašymą būtų racionalu žodžiais paaiškinti ivairiais aspektais bei detalizuoti. Todèl siekiant atlikti detalesnę Lietuvos statybos šakos analizę ir pateikti išsamias rekomendacijas jos efektyvumui didinti, būtina kiekybine ir koncepcine forma adekvačiai aprašyti nagrinejjamus veiksnius. Tai toliau bus pateikta organizaciju finansavimo pavyzdžiu (2 lentelè).

Aprašant finansavimo šaltinius suteikiamos bendrosios žinios, analizuojami jų privalumai ir trūkumai, racionalios naudojimo sritys Lietuvoje. Pavyzdžiui, iš pradžių suteikus bendruju žinių, žodžiais analizuojama, kaip šie finansavimo šaltiniai naudojami Lietuvoje, o paskui tai ịvertinama kiekybine išraiška nuo 0 (kai iš viso nenaudojami) iki 10 (kai naudojami taip, kaip išsivysčiusiose šalyse) balų. Kiekybiškai aprašant kiekvienam finansavimo šaltiniui sudaroma išsami apibūdinamoji kriteriju sistema (galimybè gauti paskolą, paskolos dydis, palūkany norma, paskolos trukmé, iqvairios nuolaidos ir pan.). Kriteriju ivairovę parodo matavimo vienety gausa.

Pavyzdžiui, palūkanų norma matuojama procentais, paskolos dydis - litais, paskolos trukmè - mènesiais ar metais, galimybẻ gauti finansavimo šaltini procentais ar balais ir pan. Kiekvieno kriterijaus reikšmès ir reikšmingumai apskaičiuojami remiantis ivairia informacija, šios srities ekspertų žiniomis ir visa tai apdorojama ekspertiniais metodais. Koncepcinio aprašymo metu pateikta kiekybiné informacija papildoma ir paaiškinama žodine. Be to, analizuojamos priežastys (informacijos nepakankamumas, îstatyminès bazès trūkumas, rizikos lygis, infliacijos lygis, valiuty keitimo kurso svyravimas ir pan.), trukdančios įdiegti ar plačiau ir veiksmingiau naudoti šiuos finansavimo šaltinius, pateikiamos konkrečios rekomendacijos šioms kliūtims pašalinti.

Siekiant pateikti detalesnes Lietuvos statybos šakos efektyvumo didinimo rekomendacijas, ir kitus veiksnius galima išsamiau aprašyti matematiškai ir žodžiais. Tad išplèstą 1 lentelę būtų galima gerokai plačiau panaudoti praktiniams tikslams. Iš jos akivaizdžiau matytume, su kokiomis problemomis susiduriama siekiant padidinti Lietuvos statybos šakos efektyvumą ir kaip šias problemas būtu galima racionaliau išspręsti.

\section{Statybos šakos plètros tendencijos išsivysčiusiose šalyse ir pasiūlymai Lietuvai}

Pagal užsienio patirtị nustačius pagrindines statybos šakos plètros tendencijas sudaromas sustambintas Lietuvos statybos šakos modelis. Tačiau siūlomų krypčiu konkretus pritaikymas Lietuvos sąlygomis priklauso nuo konkrečios situacijos. Kiekvienos šalies vyriausybés pagrindinis tikslas yra efektyviai naudojant turimus išteklius pasiekti ekonominius, socialinius, teisinius, politinius, technologinius ir kitus tikslus. Ivairiose šalyse yra nevienodos ekonominès, socialinès, teisinès ir kitokios sąlygos, ir todèl statybos šakos pletros kryptys kiekvienoje konkrečioje šalyje gali turéti daugybę igyvendinimo būdų ir priemonių. Todẻl sudarant detaly Lietuvos statybos šakos modeli pagrindines pasaulines statybos šakos plètros tendencijas reikia pritaikyti konkrečioms Lietuvos ekonominèms, socialinèms, teisinèms, politinèms, technologinèms sąlygoms. Tai galima atlikti taikant variantinio projektavimo ir daugiakriterinès analizès metodus [6].

Toliau trumpai pateikiamas statybos šakos plètros tendenciju išsivysčiusiose šalyse nustatymas ir pasiūlymų Lietuvai pateikimas būsto pavyzdžiu. Remiantis lyginamaja išsivysčiusių užsienio šalių ir Lietuvos gyvenamuju namu statybos šakos ekonominio efektyvumo faktoriu analize buvo nustatytos sritys, kuriose esama padètis atitinka, iš dalies atitinka ir neatitinka nagrinètų užsienio šaliu praktikos. Remiantis šia analize 3 lentelèje pateiktos būsto plètros tendencijos Vakary Europos šalyse ir JAV bei pasiūlymai Lietuvai [7]. 


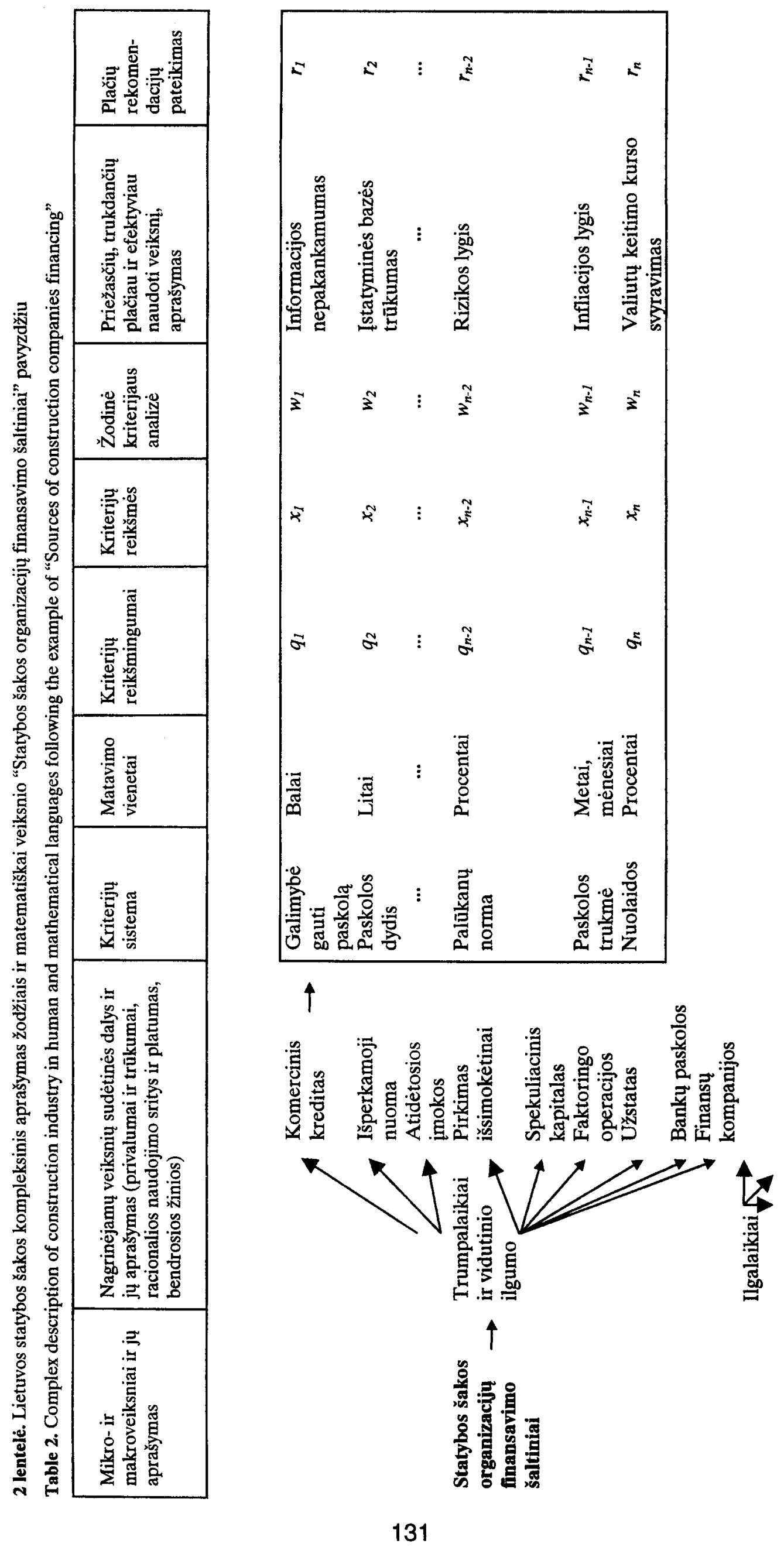


3 lentelè. Būsto plètros tendencijos Vakaru Europos šalyse ir JAV bei pasiūlymai Lietuvai

Table 3. Trends of housing development in West Europe and USA and proposals for Lithuania

\begin{tabular}{|c|c|c|}
\hline $\begin{array}{l}\text { Nagrinéjamo } \\
\text { veiksnio } \\
\text { pavadinimas } \\
\end{array}$ & Būsto plètros tendencijos Vakarı Europos šalyse ir JAV & Pasiūlymai Lietuvai \\
\hline $\begin{array}{l}\text { 1. Valstybinių } \\
\text { išlaidụ } \\
\text { sumažinimas } \\
\text { būstui }\end{array}$ & $\begin{array}{l}\text { Esant didelei išsivysčiusių šaliu būsto politikos ịvairovei galima skirti } \\
\text { kai kurias bendras kryptis. Pavyzdžiui, visos vyriausybès siekia } \\
\text { tiesiogiai sumažinti valstybès išlaidas būstui, nors tai ne visada } \\
\text { pasiseka. Jos taip pat siekia sumažinti šias išlaidas aplinkiniais keliais, } \\
\text { pavyzdžiui, mažinant netiesiogines subsidijas per mokesčių sistemą } \\
{[8] .}\end{array}$ & $\begin{array}{l}\text { Šiuo metu nemaža Lietuvos } \\
\text { gyventoju gauna nedideles } \\
\text { pajamas ir yra nepajėgūs } \\
\text { savarankiškai jisigyti arba } \\
\text { pagerinti savo būsto sąlygas. } \\
\text { Todèl neišsprendus pagrindiniu } \\
\text { būsto problemų šalyje mažinti } \\
\text { valstybines ił̌laidas (tiesiogines ir } \\
\text { netiesiogines) büstui Lietuvoje } \\
\text { nèra racionalu. }\end{array}$ \\
\hline $\begin{array}{l}\text { 2. Teisinè būsto } \\
\text { subsidijavimo } \\
\text { bazé }\end{array}$ & $\begin{array}{l}\text { Jungtinès Karalystès teisinè būsto subsidijavimo bazẻ adekvačiai } \\
\text { parodo šalies socialinę, ekonominę, politinę, pastatụ nusidèvejimo } \\
\text { būklę. }\end{array}$ & $\begin{array}{l}\text { Lietuvos teisinè būsto } \\
\text { subsidijavimo bazè turètų } \\
\text { adekvaciau parodyti šalies } \\
\text { socialinę, ekonominę, politinę, } \\
\text { pastatų nusidèvejjimo būklę bei } \\
\text { rinkos ekonomikos keliamus } \\
\text { reikalavimus. }\end{array}$ \\
\hline $\begin{array}{l}\text { 3. Būsto } \\
\text { subsidijos }\end{array}$ & $\begin{array}{l}\text { Siekiant aprūpinti būstu mažas pajamas turinčius gyventojus, paprastai } \\
\text { jiems reikia suteikti tam tikru subsidiju. Tačiau pasaulyje valstybès } \\
\text { teikiamos paramos formos būstui łsigyti nėra vienodos. Pavyzdžiui, } \\
\text { JAV parama suteikiama, jeigu išlaidos už būstą viršija 30\% šeimos } \\
\text { pajamu, kitose šalyse subsidiju galimumas ir dydis priklauso nuo } \\
\text { šeimos dydžio, pajamų, turimo turto [9]. }\end{array}$ & $\begin{array}{l}\text { Būsto subsidijų tobulinimas } \\
\text { atsižvelgiant } \mathfrak{i} \text { šalies ekonominę, } \\
\text { socialinę ir politinę padèti. }\end{array}$ \\
\hline $\begin{array}{l}\text { 4. Energijos } \\
\text { taupymo } \\
\text { priemonès } \\
\text { eksploatuo- } \\
\text { jamuose } \\
\text { pastatuose }\end{array}$ & 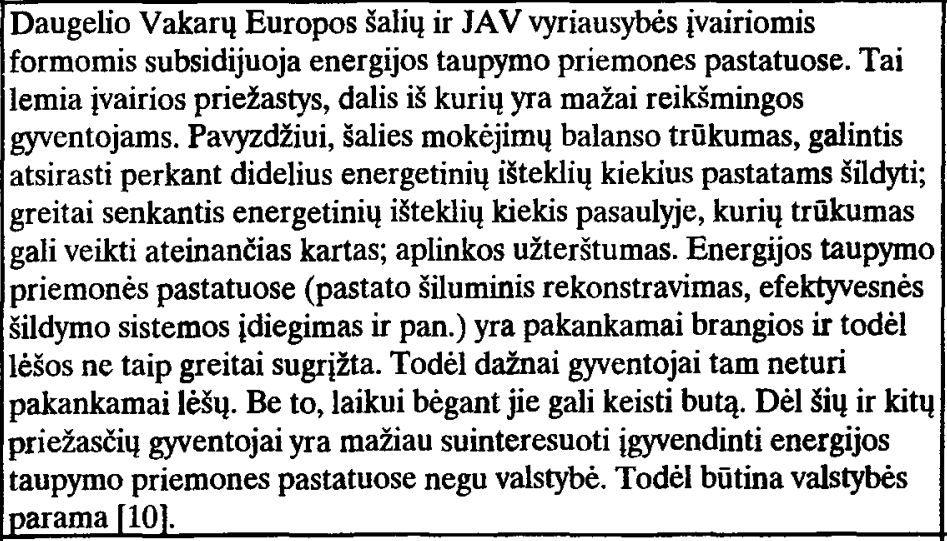 & $\begin{array}{l}\text { Ivairiomis formomis skatinti } \\
\text { gyventojus diegti energijos } \\
\text { taupymo priemones pastatuose } \\
\text { taikant mokesčiu lengvatas ir } \\
\text { subsidijas. }\end{array}$ \\
\hline $\begin{array}{l}\text { 5. Būsto } \\
\text { kreditavimas }\end{array}$ & $\begin{array}{l}\text { Tendencija naudotis nespecializuotu būsto finansu įstaigu ir dideliu } \\
\text { finansinių susivienijimų visomis finansinèmis paslaugomis, atrodo, yra } \\
\text { universali ir, matyt, neišvengiama dèl vykstančios tarptautinès } \\
\text { konkurencijos ir finansu rinkų spaudimo. Būstas kredituojamas ir } \\
\text { investuojama i ji iš juairių šaltinių ir dèl ju turima tiesiogiai varžytis su } \\
\text { kitais asmenimis ir finansu ìstaigomis šalies ir užsienio finansų rinkose } \\
{[8] \text {. }}\end{array}$ & $\begin{array}{l}\text { Sudaryti geresnes sąlygas, kad } \\
\text { šalies ir užsienio finansu îstaigos } \\
\text { teiktu palankius kreditus būstui. }\end{array}$ \\
\hline $\begin{array}{l}\text { 6. Ilgalaikès } \\
\text { paskolos }\end{array}$ & $\begin{array}{l}\text { Vyriausybès, siekdamos sudaryti geresnes ilgalaikiu paskolų gavimo } \\
\text { sąlygas, turi ịsikišti i finansu rinkas. Tai ypač svarbu šalims su } \\
\text { nusilpusiu finansu sektoriumi, pavyzdžiui, JAV per 1930-ujų metų } \\
\text { Didžiają kriz̨̧. Šs isikišimas taip pat būtinas, kai bankų sistemoje nèra } \\
\text { tradiciju suteikti ilgalaikių paskolų, pavyzdžiui, pokarinèje } \\
\text { Prancūzijoje, taip pat kai kuriuo požiüriu JAV 1920-aisiais metais [8]. }\end{array}$ & $\begin{array}{l}\text { Finansy rinkos orientavimas i } \\
\text { ilgalaikes paskolas. }\end{array}$ \\
\hline $\begin{array}{l}\text { 7. Gyvenamojo } \\
\text { fondo struktüra } \\
\text { ir kokybè }\end{array}$ & $\begin{array}{l}\text { Vieno, dviejų, trijų ir daugiau kambarių daugiabučiuose namuose bei } \\
\text { juairių vienbučiu gyvenamuju namy paklausa ir pasiūla yra skirtinga. } \\
\text { Todèl, siekiant kuo geriau patenkinti gyventoju poreikius, daugelio } \\
\text { šalių vyriausybės imasi ịvairiu priemonių, kad gyvenamojo fondo }\end{array}$ & $\begin{array}{l}\text { Siekti, kad gyvenamojo fondo } \\
\text { struktūra ir jo kokybé atitiktu } \\
\text { ivairiu gyventoju sluoksnių } \\
\text { poreikius. }\end{array}$ \\
\hline
\end{tabular}




\begin{tabular}{|c|c|c|}
\hline & struktūra ir jo kokybè atitiktų ivairiu gyventojų sluoksnių poreikius. & \\
\hline $\begin{array}{l}\text { 8. Būsto } \\
\text { problemos, } \\
\text { nesusijusios su } \\
\text { tiesiogine būsto } \\
\text { fizine struktūra }\end{array}$ & 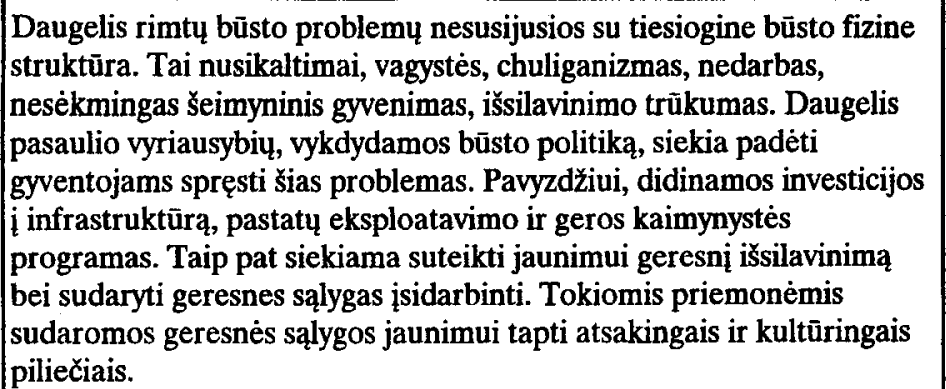 & $\begin{array}{l}\text { Didinti investicijas i } \\
\text { infrastruktūrą, pastatų } \\
\text { eksploatavimo ir geros } \\
\text { kaimynystës programas. Stengtis } \\
\text { suteikti jaunimui geresnị } \\
\text { išsilavinimą bei sudaryti geresnes } \\
\text { sąlygas j̣sidarbinti. }\end{array}$ \\
\hline $\begin{array}{l}\text { 9. Vargingi } \\
\text { būstai ar jų } \\
\text { aplinka }\end{array}$ & $\begin{array}{l}\text { Vargingi būstai yra neestetiški, nepatogūs, gali platinti ịvairias ligas ar } \\
\text { paaštrinti socialines problemas (nešvari aplinka, girtavimas, } \\
\text { chuliganizmas ir kt.). Tai ịvairiais aspektais veikia aplinkinius } \\
\text { gyventojus. Valdžia šias problemas sprendžia dviem būdais: } \\
\text { priimdama minimalius būstu ir ju aplinkos standartus bei teikdama } \\
\text { subsidijas gyventojams, nepajègiantiems pasiekti nustatytụ reikalavimu } \\
\text { lygio. }\end{array}$ & $\begin{array}{l}\text { Minimaliu reikalavimu } \\
\text { vargingiems būstams ir ju aplinkai } \\
\text { sudarymas bei subsidiju } \\
\text { gyventojams, nepajëgiantiems } \\
\text { pasiekti nustatytu reikalavimu } \\
\text { lygio, teikimas. }\end{array}$ \\
\hline $\begin{array}{l}\text { 10. Informacine } \\
\text { technologija }\end{array}$ & 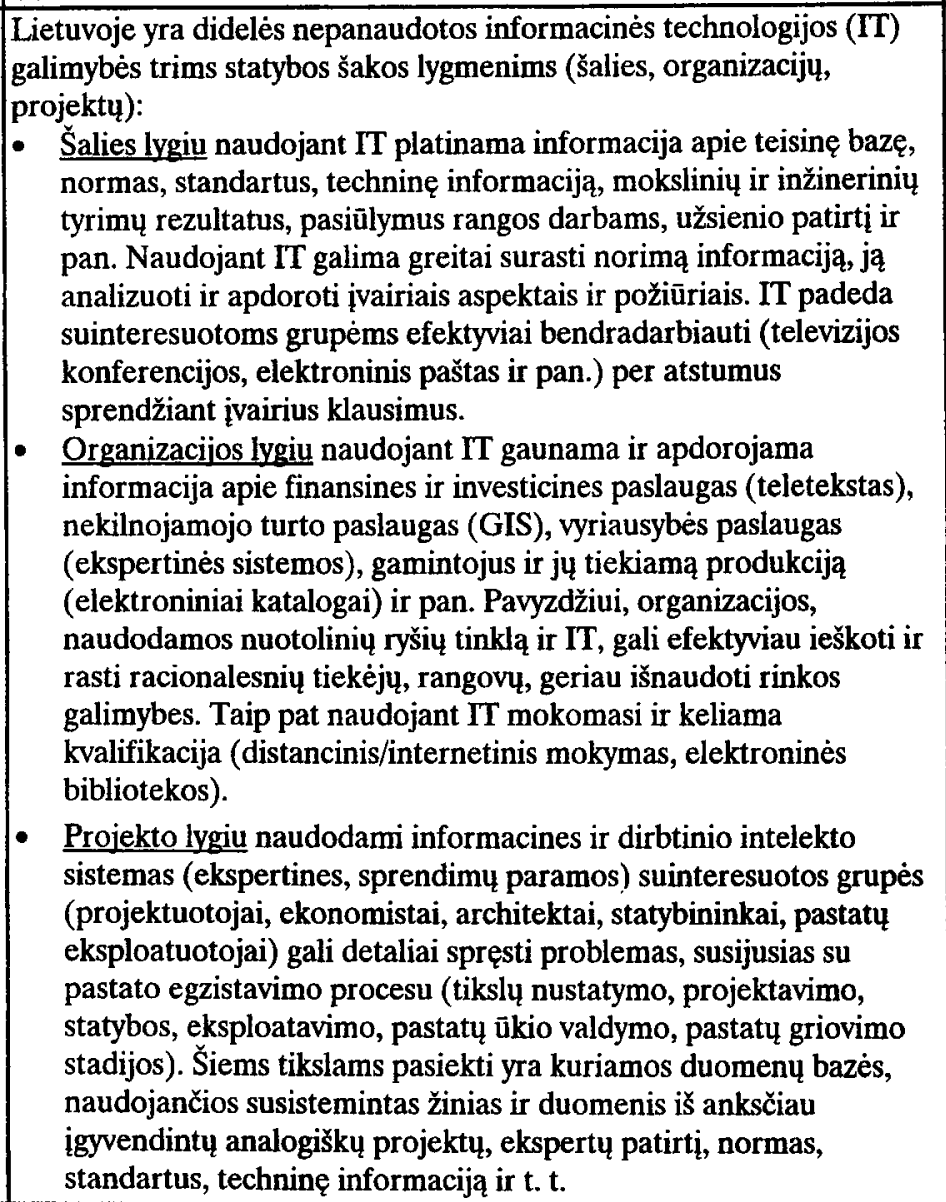 & $\begin{array}{l}\text { Sparčiau diegti informacinę } \\
\text { technologiją trimis statybos šakos } \\
\text { lygmenimis (šalies, organizaciju, } \\
\text { projektų). }\end{array}$ \\
\hline
\end{tabular}

\section{Literatūra}

1. V. Gaučaitè. Finansinè biznio plano dalis / Pramonès darbuotoju mokymo centras. Vilnius, 1993. 22 p.

2. Американская пкола управления. Бизнес-план или ках повысить доходность вашего предприятия. Предприниматель и рынок. Страховое общество "АНКИЛ", 1992.

3. Constructability. Publication 3-1, Constructability Task Force, Construction Industry Institute, Austin, Tex. 1986.
4. Экономика промышленного производства. 1992, № 2, c. 132-138.

5. A. Kaklauskas. Research output: Total life analysis, modelling and forecasting of construction in Lithuania. Ref.: Ace programme 1996. Project No: P96-6708-F. 1998.

6. B. Sloan, E. K. Zavadskas, A. Kaklauskas. Total life analysis, modelling and forecasting of the construction industry in Lithuania // Proceedings of the XXV IAHS World Housing Congress. Lisbon, Portugal 29 June - 3 July 1998. Edited by V. Abrantes. Porto, 1998, p. 69-78. 
7. E. K. Zavadskas, B. Sloan, A. Kaklauskas. Multicriteria complex analysis of European construction industry and future prognoses for Central and East European countries // Socialiniai mokslai, Vadyba, Nr. 4(8). Kaunas: Technologija, 1996, p. 68-73.

8. M. Ball, M. Harboe and M. Martens. Housing and social change in Europe and the USA. London: Routledge, $1990.224 \mathrm{p}$.

9. G. Hallett. The new housing shortage. Housing affordability in Europe and the USA. London: Routledge, 1993. 274 p.

10. P. H. Hillebrandt. Analysis of the British construction industry. London: Macmillan Press, 1988. 338 p.

Itteikta 19990304

\section{DEVELOPMENT OF RATIONAL MODEL FOR LITHUANIAN CONSTRUCTION INDUSTRY}

\section{E. K. Zavadskas, A. V. Rutkauskas, A. Kaklauskas}

\section{Su m m a r y}

By modelling and forecasting future perspectives and trends of the construction industry, it is possible to get prepared in advance to respond to the changes of macroand microlevel variables (eg enterprise restructuring and structural change, sources of company finance, information system of construction, financial sector, interest rate, inflation, innovation, etc) which affect the Lithuanian economy.

The lifetime process model suggested by this research is based on the presumption that the efficiency of the construction industry depends on many micro- and macrolevel variables. The presence of specific macro- and microlevel variable factors immediately imposes objective limitations for the efficient use of the resources of the construction industry. The construction industry, in the presence of these limitations, performs its functions within these constraints as efficiently as possible. For instance, construction organisations, being influenced by particular macro- and microlevel environment variables, would do their best to undertake the activities within restricted aspects of the construction industry (eg designing, production of building materials, construction of dwellings, thermal refurbishment of buildings, etc), geographic locations, and with such interested parties, where the goals of all parties would find maximum satisfaction.

Organisations which base themselves on this assertion, try to create a rational environment and operating conditions to achieve the best satisfaction of their customers' needs, to win a better reputation and to earn more profit. Therefore, based on the main development trends of the construction industry (in advanced industrial economies), it is possible to develop recommendations on how to increase the efficiency of the transitional construction industry in Lithuania.

This research seeks to produce a model of the rational construction industry in Lithuania by undertaking a complex analysis of micro- and macroenvironment factors affecting it and to give recommendations on the increase of its competitive ability. Simulation modelling was undertaken to provide insight into how to create an effective environment for the construction industry by choosing rational microand macrofactors.

This research seeks to explore ways of harmonising the relationship between the transitional Lithuanian construction and its environment. The research outlines the changing nature of the Lithuanian transitional construction economy, examines the effect of the changing external environment on the efficiency of the construction industry, proposes a theoretical model representing the current situation in Lithuania and presents a model for an efficient environment in the Lithuanian construction industry.

While the construction organisations cannot alter the micro- and macrolevel variables, they can assess their impact and take them into consideration when realising projects. Organisations, being aware of the micro- and macrolevel factors which affect the projects being realised, should be able to organise their present and future activities more successfully.

Edmundas Kazimieras ZAVADSKAS. Doctor Habil, Professor. Rector of Vilnius Gediminas Technical University. Member of Lithuanian Academy of Sciences. Member of Ukrainian Academy of Technological Cybernetics. Vilnius Gediminas Technical University, Sauletekio al. 11, 2040 Vilnius, Lithuania.

In 1973 Dr degree in building structures. Professor at the Dept of Building Technology and Management. In 1987 Dr Habil degree (problems of building technology and management). Research visits to Moscow Civil Engineering Institute, Leipzig and Aachen Higher Technical Schools. He maintains close academic links with the universities of Aalborg (Denmark), Salford and Glamorgan (Great Britain), Poznan University of Technology (Poland), Leipzig Higher School of Technology, Economics and Culture (Germany) and Aachen Higher Technical School (Germany). Member of international organizations. Member of steering and programme committees of many international conferences. Member of editorial boards of some research journals. Author of monographs in Lithuanian, English, German and Russian. Research interests: building technology and management, decisionmaking theory, automation in design, expert systems.

Aleksandras Vytautas RUTKAUSKAS. Doctor Habil, Professor. Head of Dept of Business and Economics. Vilnius Gediminas Technical University, Sauletekio al. 11, 2040 Vilnius, Lithuania.

Research interests: economics, decision-making under risk and uncertainty, mathematics of finance.

Artūras KAKLAUSKAS. Doctor, Associate Professor. Dept of Building Technology and Management. Vilnius Gediminas Technical University, Saulètekio al. 11, 2040 Vilnius, Lithuania.

PhD degree in 1990. Research visits to Aalborg University (Denmark, 1991), the University of Glamorgan, UK (1993/1995). Author and co-author of 3 monographs and more than 50 papers. Research interests: the theory of multiple criteria decision-making, expert systems, total quality management, computer-aided design. 